研究

\title{
高い疲れ限度比を有する焼結メカニカルヒューズ部品の開発
}

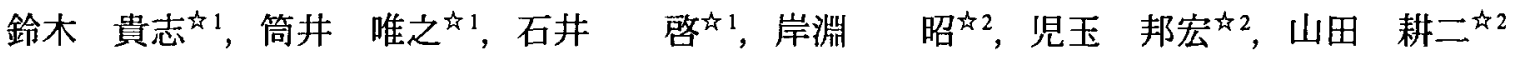

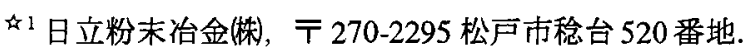 \\ 蝴デンソー, テ 448-8661 刈谷市昭和町 1-1.
}

\section{Development of Sintered Mechanical Fuse Parts with High Fatigue Limit Ratio}

\author{
Takashi Suzuki ${ }^{\text {t } 1}$, Tadayuki Tsutsui ${ }^{\text {tै }}$, Kei Ishii ${ }^{\text {tै } 1}$, Akira Kishibuchi tै 2 , \\ Kunihiro Kodama ${ }^{\text {th } 2}$ and Kouji Yamada ${ }^{\text {th }}$ \\ ${ }^{1}$ Hitachi Powdered Metal Co.,Ltd., 520 Minoridai, Matsudo 270-2295. \\ 2DENSO CORPORATION, 1-1 Showa-cho, Kariya 448-8661.
}

Received July 9, 2004

\begin{abstract}
SYNOPSIS
It is required a function that the compressor of a car air conditioner in case overloaded will be disconnected from the engine power. Presented here is the development of a mechanical fuse part having such function. This part can be realized by satisfying two functions simultaneousiy; (1) the part has sufficient fatigue strength to transmit power without breaking, and (2) it breaks promptly to disconnect the power if an overload occurs. This can be realized by developing a material having high fatigue limit ratio (fatigue strength/tensile strength). Such material was investigated and was found that a high fatigue limit ratio is achieved by steam treating a $\mathrm{Fe}-\mathrm{Cu}-\mathrm{C}$ material sintered compact with a decreased amount of carbon. This newly developed material has recently been applied to such required mechanical fuse parts.
\end{abstract}

KEY WORDS

Compressor, mechanical fuse, fatigue limit ratio, steam treatment

\section{1 緒 言}

近年のカーエアコン用のコンプレッサは省然費，省動力， 加速性の向上および電磁クラッチの断続時におけるショック の低隇を目的として連続可変容量化へのニーズが高まりつつ ある1!この用途のコンプレッサは万がーコンプレッサに過大 な負倚が加わった際にベルトを保護する機能が必要となる。 このため，一定以上の負荷を生じると動力を伝達する部分の 一部が破断することでエンジンからの動力云達を遮断しベル トを保護する，いわゆるメカニカルヒューズ部品の開発を 行った. プーリとコンプレッサの軸を連結する部位に用いる 本製品は，以下の機能を満足する必要がある．(1)通常の運転 時は破断することなく動力を伀達するための疲れ強さを有す る. (2)コンプレッサに過大な負荷が损わった際は動力を伝達 する部分の一部が速やかに破断することで動力を遮断する. このため，材料は高い疲れ限度比(疲れ強さ/引張り強さ)が 求められる イト組織に比べてフェライト組織が高い疲れ限度比が得られ， C量の低下により疲れ限度比は向上することが知られている3,4.
そこで, 本研究では粉末冶金において広く使用されている Fe$\mathrm{Cu}-\mathrm{C}$ 系の材料を用いて，疲れ限度比に及法す黒鈴の添加量の 影響を確認した，さらに，気孔の球状化による応力集中の緩 和に着目し，疲れ限度比に及ぼすスチーム処理の影響につい て検討を行った。

\section{2 試料及び実験方法}

\section{1 試料の作製}

原料粉はJFE スチール(侏製の $180 \mu \mathrm{m}$ 以下の還元鉄粉 (JIP270MS), $45 \mu \mathrm{m}$ 以下のアトマイズ銅粉 (KCU-EL)，日本黒 鉛工業侏製の平均粒径 $5 \mu \mathrm{m}$ の天然黒鉛粉 (J-CPB)，および成 形潤滑郕として陽光座業侏製のステアリン酸覀鉆粉(ZNS730) を用いた. Table 1は各原料粉の配合比を示す. 各々の混合粉 は引張り試験片と回転曲げ疲労試験片用の素材として $15 \times 90$ $\times 15 \mathrm{~mm}$, 残留応力測定用の素材として $10 \times 60 \times 3 \mathrm{~mm}$ の形状 を密度 $6.50 \pm 0.05 \mathrm{Mg} / \mathrm{m}^{3}$ になるように成形した. 各成形体は工 ンドサーミックガス霉囲気中で $1393 \mathrm{~K}$ ，保持時間 $1.2 \mathrm{ks}$ の条件 で焼結した. 一部の焼結体は水蒸気中で温度 $853 \mathrm{~K}$ ，保持時間 
$1.2 \mathrm{ks}$ の条件でスチーム処理を行った.

\section{2 評価方法}

\section{2 .1 疲れ限度比に及ぼすスチーム処理の影響}

暁結体とスチーム体の疲れ限度比はTable 1に示す試料No.1 の引張り強さと疲れ強さを測定し求めた. Fig.1は引張り試験 片, Fig.2は疲れ試験片を示す.引張り強さはISO 6892に準拠 し测定した．疲れ強さは小野式回転曲げ疲れ試験により繰り 返し数 $1 \times 10^{7}$ で末破断の応力を測定した.

2.2.2 気孔の球状化と残留応力に及ぼすスチーム処理の影響

残留応力は試料No.1の焼結体とスチ一ム体の表面をX線に より格子定数の変化を湘定し残留店力を求めた，気孔分布は 試料No.10焼結体とスチーム体を熱硬化性樹脂に埋込み研摩 したのち観察した．この気孔分布は解析ソフトWinroof ver.3 を用いて画像解析し, 気孔の球状化度合いを表す指標として (1)式により気孔の円形度を測定した。

$$
\mathrm{D}=4 \pi \mathrm{S} / \mathrm{L}^{2}
$$

ここで, 式中の $\mathrm{D}$ は気孔の円形度 $(0<\mathrm{D} \leqq 1), \mathrm{S}$ は気孔の面 積，Lは気孔の周囲長であり，Dが 1 に近いほど気孔がより球 状化していることを表す. 研摩した試料はSEM観察および元 素分析を行った。

\subsection{3 疲れ限度比に及ぼす黒鈶の添加量の影響}

Table 1に示す試料のスチーム体の疲れ限度比は2.2.1と同様 の方法で求めた。

\subsection{4引張り試験と疲れ試験における亀裂伝播の解析}

引張り試験と疲れ試験における亀裂伝播を解析するため, 2.2.1で評価した焼結体の試料は 3\% ナイタール液により試料 の表面を腐食したのち光学顕微鏡で観察した.なお，疲労試 験における亀裂伝播は，繰り返し数 $5 \times 10^{5}$ 前後で破断する予 想応力を負荷した時に，繰り返し数 $1 \times 10^{5}$ で試験を中断して 観察した.

\section{3 実験結果および考察}

\section{1 疲れ限度比に及ぼすスチーム処理の影響}

Fig.3 は試料No.1の焼結体とスチーム体の引張り強さを示 す.スチーム処理による引張り強さの変化はほとんどなく, 煐結体とスチーム体は同等の引張り強さを示す. Fig.4注試料 No.1の焼結体とスチーム体の疲れ強さを示す，スチーム体は 焼結体に比べて疲れ強さが 36\% 上昇する. Fig.5 は Fig.3,4よ り求めた試料No.1における焼結体とスチーム体の疲机限度比 を示す．スチーム体の疲れ強さは 0.46 であり，焼結体の 0.36

Table 1 Chemical compositions.

(wt. \%)

\begin{tabular}{|c|c|c|c|c|}
\hline No. & $\begin{array}{c}\text { Fe } \\
\text { Powder }\end{array}$ & $\begin{array}{c}\mathrm{Cu} \\
\text { Powder }\end{array}$ & $\begin{array}{c}\text { Graphite } \\
\text { Powder }\end{array}$ & Lubricant \\
\hline 1 & 98.2 & $\mathbf{1 . 5}$ & 0.3 & 0.8 \\
\hline 2 & 98.0 & 1.5 & 0.5 & 0.8 \\
\hline 3 & 97.8 & 1.5 & 0.7 & 0.8 \\
\hline
\end{tabular}

に比べて $28 \%$ 上昇する.このことから，スチーム処理は疲れ 限度比の上昇に有効と考える.

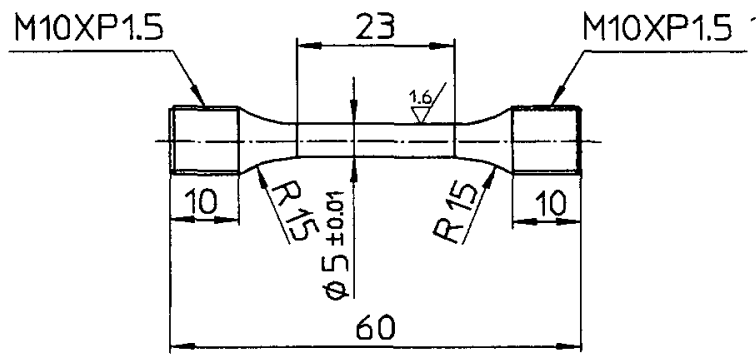

Fig.1 Specimen for tensile strength

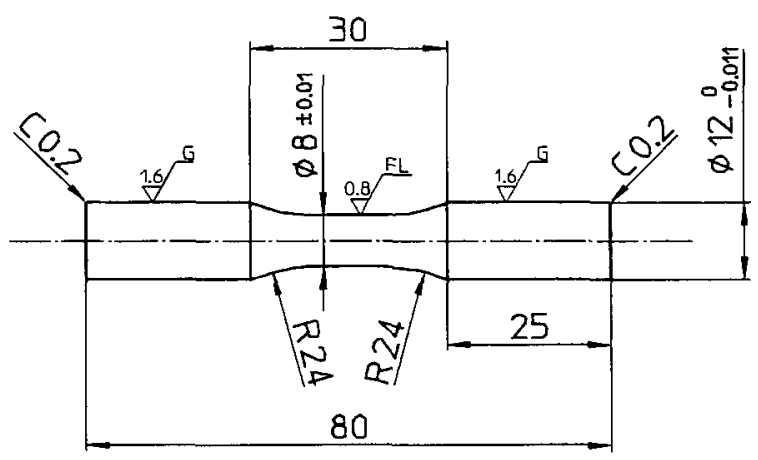

Fig.2 Specimen for fatigue strength

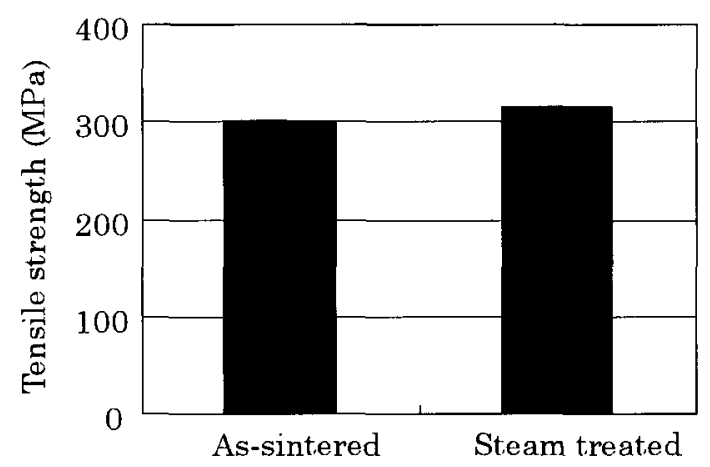

Fig.3 Comparison of tensile strength in specimen No.1.

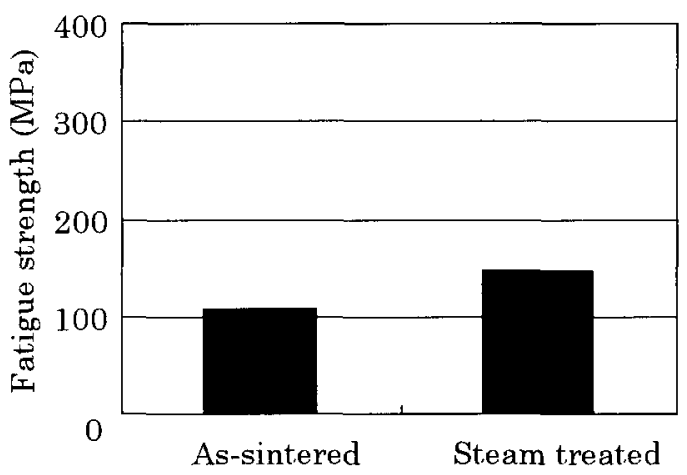

Fig.4 Comparison of fatigue strength in specimen No.1. 


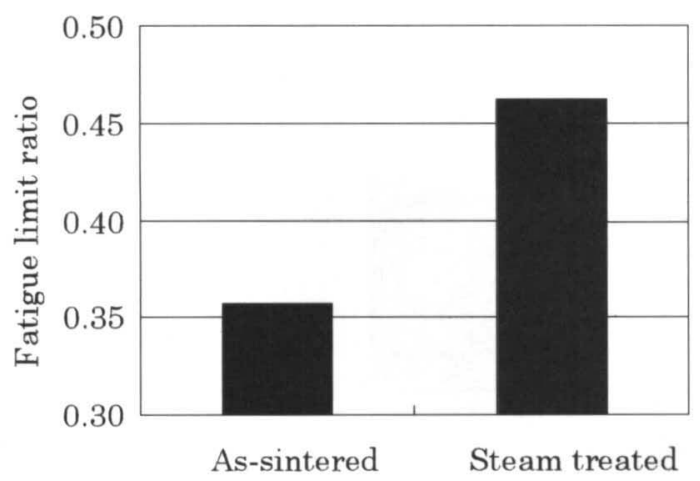

Fig.5 Comparison of fatigue limit ratio in specimen No.1.

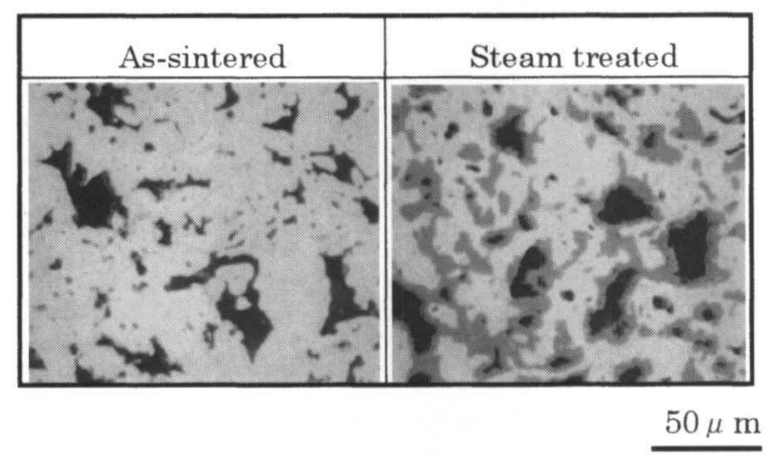

Fig.6 Pore distribution in specimen No.1.

Table 2 Comparison of pore roundness and residual compressive stress in specimen No.1.

\begin{tabular}{|c|c|c|}
\hline & As-sintered & Steam treated \\
\hline $\begin{array}{c}\text { Pore } \\
\text { roundness }\end{array}$ & 0.30 & 0.47 \\
\hline $\begin{array}{c}\text { Residual } \\
\text { compressive } \\
\text { stress (MPa) }\end{array}$ & 42.0 & 75.5 \\
\hline
\end{tabular}

\section{2 気孔の球状化と残留応力に及ぼすスチーム処理の影響}

Fig.6は焼結体とスチーム体の気孔分布を示す. スチーム体 は焼結体に比べて気孔が球状化している様子が観察できる. Table 2 は気孔の円形度と残留応力を示す. スチーム処理によ り, 気孔の円形度は増加している. また，スチーム処理は圧 縮残留応力を付与することができる. Fig.7は焼結体とスチー ム体のSEM像と元素分析の結果を示す. スチーム体における 気孔の外周は酸化物層が形成されている. 以上より，スチー ム処理は気孔の外周に酸化物層を形成し, 疲労の起点となる 鋭角部が減少することや圧縮残留応力が付与されるために, 疲れ強さが向上すると考える. しかしながら, 引張り強さは スチーム処理によりほとんど変化しないことから, スチーム 体は焼結体に比べて疲れ限度比が上昇する。

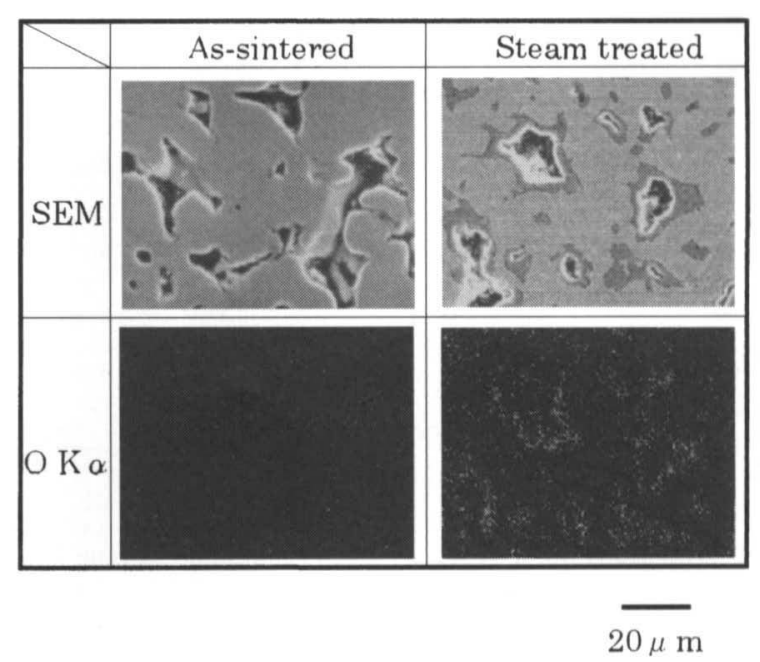

Fig.7 Distribution of oxide in specimen No.1.

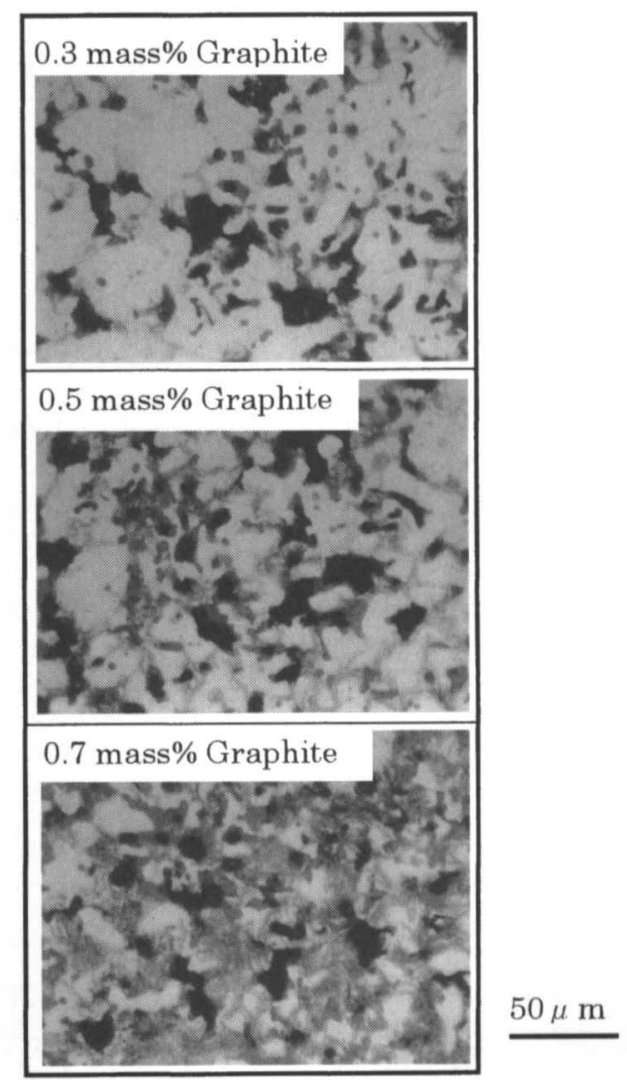

Fig.8 Microstructures of steam treated specimens of table 1 .

\section{3 疲れ限度比に及ぼす黒鉛の添加量の影響}

Fig.8 は試料 No.1〜 3 におけるスチーム体の金属組織を示 す. 添加する黒鉛量の増加に伴いパーライトが増加する. Fig.9は試料No.1〜3におけるスチーム体の引張り強さと疲れ 強さの関係を示す. 添加する黒鉛量の増加に伴い引張り強さ は上昇するのに対し, 疲れ強さはほとんど変化しない. Fig.10 は試料No.1〜3のスチーム体における添加する黒鉛量と疲れ 


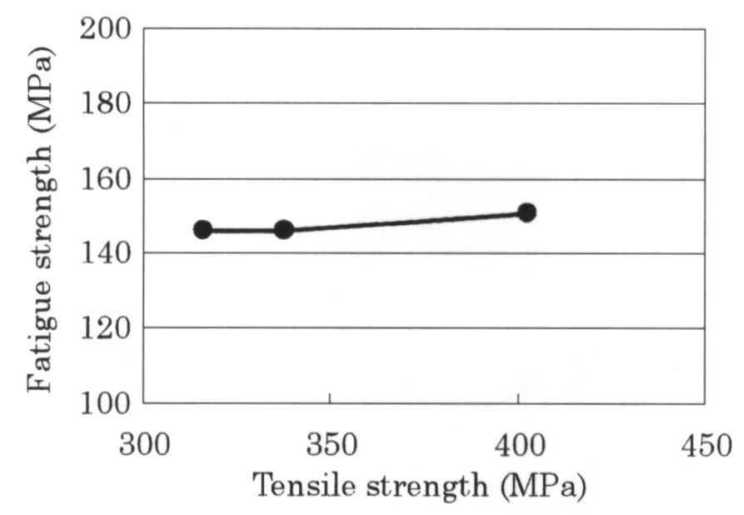

Fig.9 Relationship between tensile strength and fatigue strength of steam treated specimen.

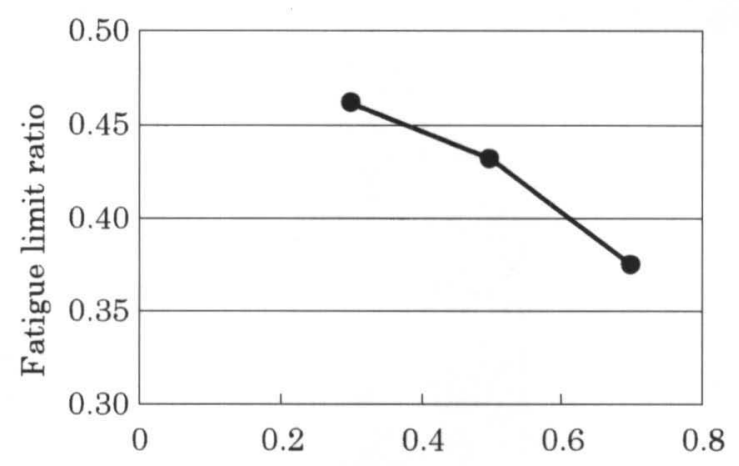

Amount of added graphite powder (mass\%)

Fig.10 Relationship between amount of added graphite and fatigue limit ratio of steam treated specimen.

限度比の関係を示す. 添加する黒鉛量の増加に伴い疲れ限度 比は低下する。

\section{4 引張り試験と疲労試験における亀裂伝播の解析}

Fig.11は3.1で評価した引張り試験と疲労試験における亀裂 伝播を観察した結果を示す. 静的 (引張り)破壊の場合, 亀裂 はいずれの組織をも层播している, 一方, 疲労破壊の場合, 亀 裂はパーライトを迁回しフェライト組織中を伝播している. すなわち, 静的破壊における刍裂はフェライトとパーライト の両方を進展するためパーライトの面積率の増加に伴い引張 り強さは上昇するが, 疲労破壊における亀裂はフェライトを 選択的に進展するためパーライトの面積の増加に伴う疲強 さの上昇する割合が少ないことが推察される. 以上のことか ら, 添加する黒鉛量の増加に伴いパーライトの面積率が増加 し疲れ限度比が低下すると考える.

\section{4 ま と め}

粉末冶金において広く使用されている $\mathrm{Fe}-\mathrm{Cu}-\mathrm{C}$ 系の材料を 用いて, 高い疲れ限度比が得られる材料を検討した結果, 以 下の結論を得た.

(1) スチーム処理により,気孔の外周に酸化物層を形成し引張 り強さはほとんど変化せずに, 気孔の球状化, 圧縮残留応

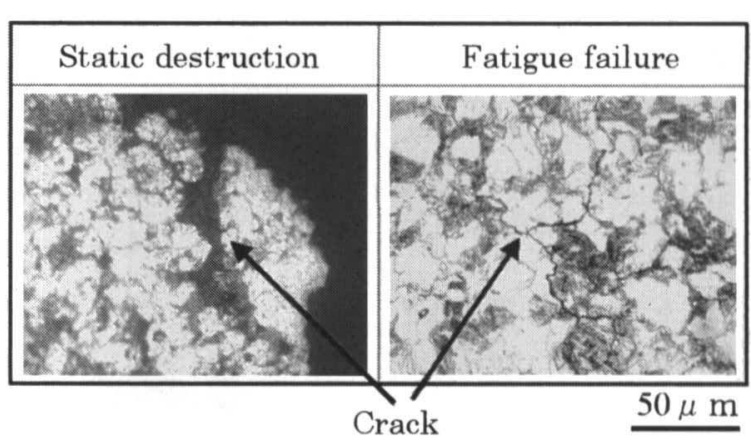

Fig.11 Appearance of crack propagation in static (tensile) destruction and fatigue failure.

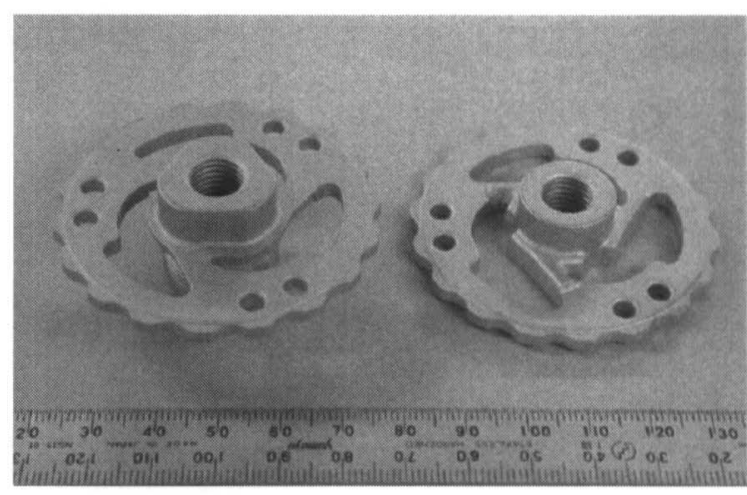

$\begin{array}{ll}\text { Material composition } \quad: \text { Fe-1.5Cu-0.4C } \\ \text { Density } & : 6.60 \mathrm{Mg} / \mathrm{m}^{3} \\ \text { Fatigue limit ratio } & : 0.57\end{array}$

Fig.12 Sintered mechanical fuse for compressors of car air conditioners.

力の付与により疲れ強さが向上する. このため, スチーム 体は焼結体に比べて疲れ限度比が上昇する.

(2) 添加する黒鉛量の増加に伴い引張り強さは上昇するが, 疲 れ強さの上昇はわずかである.このことから, 添加する黒 鉛量の増加に伴い疲れ限度比は低下する。

(3) 静的強さはフェライトとパーライトの比率により決定され るため,パーライトの面積率の増加に伴い引張り強さは上 昇する. 一方, 疲れ強さは疲労亀裂の伝播がフェライトを 選択的に進展するため, パーライトの面積率に伴う疲れ強 さの上昇する割合が少ない。

(4) 添加する黒鉛量を低隇し，さらにスチーム処理を施した $\mathrm{Fe}-\mathrm{Cu}-\mathrm{C}$ 系の焼結材料は高い疲れ限度比が得られる。

\section{5 適 用 例}

Fig.12 は本研究で得られた知見をもとに開発したカーエア コン・コンプレッサ用のメカニカルヒューズ部品である. 本 製品に適用している材料は, 気孔の球状化を目的としてス チーム処理の条件を最適化することにより, 疲れ限度比は 0.57 を達成している. 


\section{文献}

1) Y.Aoki, J.Ohguchi, K.Yamada, Y.Tanimura, H.Oka and N.Hakamada: "Development of DL pulley for variable displacement compressor -development of metal breakage type torque limiter-", Proceedings of 2002 Spring Conference of Society of Automotive Engineers of Japan, No.64-02(2002)1316.

2) T.Suzuki, T.Tsutsui, K.Ishii, J.Ohguchi, K.Yamada and
K.Kodama: "The Development of a Sintered Mechanical Fuse for Compressors of Car Air Conditioners", Proceedings of 2003 Autumn Conference of the Japan Society of Powder and Powder Metallurgy, (2003) 112.

3) The Japan Institute of Metals: "Strength and Destruction of Metallic Materials", Maruzen, (1964)396.

4) M.Ikeda and G.Anan: "High Strength Microalloyed Steels", KOBE STEEL ENGINEERING REPORTS, 52(2002)47-51. 